\title{
Rebels, Revenue and Redistribution: The Political Geography of Post-Conflict Power-Sharing in Africa
}

\author{
Felix Haass ${ }^{1 \star}$ (D) and Martin Ottmann ${ }^{2}$ \\ ${ }^{1}$ Arnold-Bergstraesser-Institute; GIGA German Institute of Global and Area Studies; University of Osnabrück and \\ ${ }^{2}$ International Development Department, School of Government, University of Birmingham, UK \\ ${ }^{*}$ Corresponding author. E-mail: felix.haass@giga-hamburg.de
}

(Received 13 December 2018; revised 17 May 2019; accepted 18 July 2019; first published online 19 February 2020)

\begin{abstract}
Do rebel elites who gain access to political power through power-sharing reward their own ethnic constituencies after war? The authors argue that power-sharing governments serve as instruments for rebel elites to access state resources. This access allows elites to allocate state resources disproportionately to their regional power bases, particularly the settlement areas of rebel groups' ethnic constituencies. To test this proposition, the authors link information on rebel groups in power-sharing governments in post-conflict countries in Africa to information about ethnic support for rebel organizations. They combine this information with sub-national data on ethnic groups' settlement areas and data on night light emissions to proxy for sub-national variation in resource investments. Implementing a difference-in-differences empirical strategy, the authors show that regions with ethnic groups represented through rebels in the power-sharing government exhibit higher levels of night light emissions than regions without such representation. These findings help to reconceptualize post-conflict power-sharing arrangements as rent-generating and redistributive institutions.
\end{abstract}

Keywords: post-conflict; power-sharing; political economy; distributive politics; Africa

Distributional conflict lies at the heart of many contemporary civil wars. In negotiated settlements to civil wars, government and rebels therefore sometimes resort to wealth-sharing arrangements, natural resource management institutions or territorial decentralization to resolve disagreements over redistributive politics (Bakke 2015; Binningsbo and Rustad 2012). Often, however, these mechanisms are not part of a peace agreement to begin with, or are only implemented years after the fighting has stopped (Ottmann and Vüllers 2015). Instead, power-sharing governments - typically transitional cabinets in which both rebel and government elites hold minister portfolios - are the most common provision in peace agreements (see Figure 1).

The literature offers different explanations of how such executive power-sharing institutions solve the distributional problem of civil conflicts. Some argue that power-sharing governments solve a commitment problem between former battlefield opponents by providing access to decision-making power (Gates et al. 2016; Hartzell and Hoddie 2003; Walter 2002). Others point to the redistributive potential of post-conflict power-sharing, specifically at the elite and ethnic group levels (Cederman, Gleditsch and Buhaug 2013; Dal Bó and Powell 2009; Lijphart 1977). But whether power-sharing governments actually realize this redistributive potential has not been sufficiently investigated. Do rebel elites who gain access to political power through power-sharing reward their own ethnic constituencies after war?

(C) Cambridge University Press 2020. This is an Open Access article, distributed under the terms of the Creative Commons Attribution licence (http://creativecommons.org/licenses/by/4.0/), which permits unrestricted re-use, distribution, and reproduction in any medium, provided the original work is properly cited. 

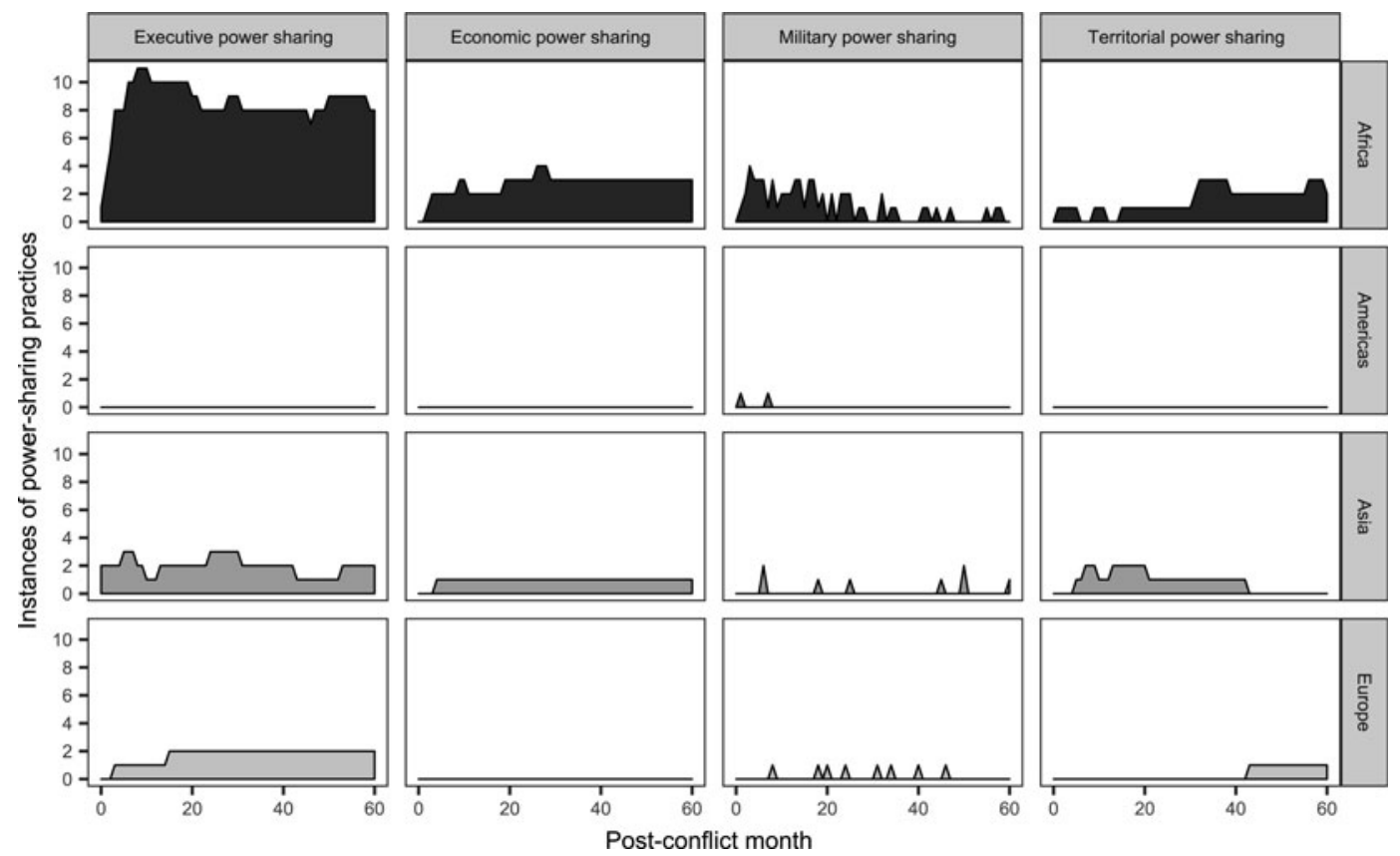

Figure 1. Practices of post-conflict power-sharing types across world regions

Note: own depiction based on information the Power-Sharing Event Dataset (PSED) (Ottmann and Vüllers 2015).

We build on theories about ethnic redistribution in non-conflict contexts and rent allocation in state building to answer this question (Acemoglu and Robinson 2000; Ejdemyr, Kramon and Robinson 2018; Francois, Rainer and Trebbi 2015; North, Wallis and Weingast 2009; Tajima, Samphantharak and Ostwald 2018). We theorize that in a power-sharing cabinet, rebel elites and with them their ethnic constituents - gain access to state resources through direct cabinet-level government participation. Modeling rebel and government elites as rent- and officeseeking agents implies that both sides steer resources to their constituencies as elites seek to secure political support from their constituencies in exchange for preferential resource allocation (Bueno de Mesquita et al. 2003). Such favoritism overlaps with the geography of ethnic settlements that fuels much of the civil war violence between the political center and the periphery (Boone 2003; De Luca et al. 2018; Herbst 2000). We therefore hypothesize that the redistributive effect of power-sharing expresses itself in rebels' preferential treatment of the sub-national settlement areas of ethnic groups on whose support rebels relied during the war. Ultimately, this preferential treatment should be visible as more pronounced economic development in the settlement areas of rebels' ethnic support groups compared to groups excluded from power-sharing, or groups that now have to share a piece of the economic pie.

To test this prediction, we construct a dataset that captures patterns of sub-national economic development in seven post-conflict countries in Africa. Africa is the world region with the highest number of civil conflicts and, consequently, the most attempts to solve these wars with negotiated settlements (Kreutz 2010). Our empirical focus on Africa therefore ensures that we gather specific knowledge on how a large portion of today's civil wars are resolved. Moreover, from a research design perspective, focusing on Africa allows us to implicitly control for important context factors, such as the political role of ethnicity (Rosenbaum 2002), which improves the internal validity of our findings (Samii 2016).

Our starting point is the Power-Sharing Event Dataset (PSED), which provides us with finegrained data on the occurrence, type and duration of rebel participation in post-conflict power- 
sharing (Ottmann and Vüllers 2015). We combine this data with information on the ethnic affiliations of rebel groups and the geographic location of ethnic groups provided by the Ethnic Power Relations (EPR) datasets (Vogt et al. 2015). We measure our dependent variable - sub-national variation in economic development - using satellite data on the nighttime light intensity for each grid cell (Tollefsen, Strand and Buhaug 2012). Changes in night light emissions plausibly reflect differences in resource investments and local economic development, especially in contexts where other information sources about resource investments are scarce (Henderson, Storeygard and Weil 2012; Weidmann and Schutte 2017).

Our empirical strategy exploits the over-time variation in night light emissions using a difference-in-differences approach. We statistically compare regions that are 'treated' with representation in the power-sharing government to regions that are not represented in the executive before and after the implementation of the agreement. The difference-in-differences strategy is particularly powerful since it allows us to control for a number of important time-invariant confounders, such as baseline differences in local economic development or ethnic heterogeneity. To rule out time-variant alternative explanations for uneven post-conflict economic recovery, we control for population and conflict intensity and construct placebo tests for non-treated groups.

Consistent with our theoretical prediction, we find robust support that power-sharing increases night-time light intensity in areas inhabited by ethnic groups linked to rebel elites in power-sharing governments. In support of the postulated redistributive mechanism, we show that this effect is more pronounced when rebel elites have better access to resources, for instance by occupying cabinet portfolios that manage the country's economy, resources or infrastructure. Moreover, we find a stronger effect in grid cells occupied by the ethnic group from which the rebel leader originates, and a weaker effect in ethnically heterogeneous regions - a pattern consistent with a strategy of preferentially targeting politically important constituencies while simultaneously disadvantaging regions in which it is difficult to identify ethnic supporters.

This article makes two notable contributions. First, we propose a political economy model of post-conflict power-sharing. Prior studies have mainly focused on how power-sharing governments provide guaranteed participation in the political decision-making process (Gates et al. 2016; Hartzell and Hoddie 2003; Walter 2002). While these studies emphasize the important role that elites and their constituencies play in the pacifying function of power-sharing, they largely disregard the potential redistributive effects of power-sharing between elites and their constituencies. Other researchers have made this redistributive potential of power-sharing more explicit, particularly when it comes to horizontal inequalities among elites and ethnic groups in the periphery (Cederman, Gleditsch and Buhaug 2013; Dal Bó and Powell 2009; Francois, Rainer and Trebbi 2015; Lijphart 1977).

Missing from both strands of research, however, is a theory and evidence of how power-sharing exploits this redistributive potential. In this article, we address this gap. We break up the unitary, rebel group-level focus into rebel elites and their geographically concentrated ethnic constituencies. Building on insights from the literature on ethnic redistribution and rent allocation in state development, we identify this elite-ethnic constituency relationship as a central axis along which post-conflict redistribution should take place (Acemoglu and Robinson 2000; Bates 2008; North, Wallis and Weingast 2009). This approach demonstrates empirically that the eliteconstituency relationship in power-sharing institutions not only has a security dimension (Gates et al. 2016), but also an important economic one. Moreover, it clarifies how power-sharing shapes distributional politics in the context of ethnically divided societies to address horizontal inequalities (Cederman, Gleditsch and Buhaug 2013).

Secondly, our study adds to the literature on redistributive politics and ethnic favoritism. Research on rebels' civilian wartime constituencies (Kalyvas 2006) implicitly suggests that elite-constituency relationships should also shape redistributive politics after conflict. Yet the literature on distributive politics in the developing world lacks an explicit theoretical and empirical focus on post-conflict settings, particularly at the disaggregated geographical level (Golden and 
Min 2013). In contrast, and in line with existing research from non-conflict contexts, we show that ethnic favoritism in post-conflict contexts is particularly prevalent in ethnically homogeneous regions. We therefore add to the finding that ethnic segregation can improve partial public goods provision (Ejdemyr, Kramon and Robinson 2018; Tajima, Samphantharak and Ostwald 2018) evidence from a context in which ethnic segregation is particularly salient: in the aftermath of civil war.

\section{The political geography of power-sharing}

We build our political economy theory on the definition of power-sharing as institutions that allocate '[...] decision-making rights, including access to state resources, among collectivities competing for power' (Hartzell and Hoddie 2003, 320). Scholars typically distinguish between different variants of power-sharing institutions that address distinct political questions. Political power-sharing arrangements regulate access to and the distribution of power by granting rebels minister positions or parliamentary quotas. Territorial arrangements regulate questions of regional autonomy. Military arrangements integrate insurgent and national armies. Finally, economic arrangements resolve questions of resource redistribution (Hartzell and Hoddie 2003).

We challenge this conceptual distinction and the implicit assumption that power-sharing has economic and geographic implications only in explicit economic and territorial arrangements. Instead, political power-sharing, most notably in the form of power-sharing governments at the political center of a country, has an economic and regional dimension, too. This regional dimension results from limited territorial authority in remote areas and the economic value of political office.

\section{Securing wealth from power}

In his analysis of African states, Herbst $(2000,151)$ explains that the 'physical control of the capital cannot be equated with control of these countries'. Yet it is the capital where significant resource flows in the form of aid, tax and natural resource income as well as international legitimacy reside. Wherever elites face such situations of limited territorial control, the central government must negotiate with rural elites over institutional arrangements that satisfy both the central government's and rural elites' interests (Boone 2003). Power-sharing governments represent the outcome of such negotiations over territorial authority in an extreme case: in the aftermath of violent rebellion.

In addition to representing territorial arrangements between central and peripheral elites, powersharing governments also secure 'wealth from power' for participating elites (Bates 2008, 43). Rebel organizations' admission to the power-sharing government gives them a unique opportunity to access state revenues - access the rebel side did not have during the war. As this temporal variation in access to state resources for rebel groups is absent for the government side in a power-sharing government, we focus predominantly on redistribution by rebel elites in power-sharing executives. ${ }^{1}$

Power-sharing governments institutionalize access to state resources for rebel elites through the distribution of minister positions in the post-conflict cabinet. Obviously, executive powersharing is not the only way to access state resources. Rebel elites can also gain this access through high-ranking military positions or guaranteed shares of parliament seats. In the large majority of post-conflict countries, however, it is the executive where political power, and thus a pathway to patronage resources, is located (Rainer and Trebbi 2016). This is particularly true in the African context, where 'ministers not only have a hand in deciding where to allocate public resources,

\footnotetext{
${ }^{1}$ Cabinet reshuffles also occur on the government side in power-sharing cabinets. But even though the peace process might alter which individual elites participate in the eventual power-sharing government, the government side's ethnic support groups typically do not vary in their access to state resources through their government representatives.
} 
presumably in their home districts, but are also in positions to supplement their personal incomes by offering contracts and jobs in exchange for other favors' (Arriola 2009, 1346). ${ }^{2}$

We assume that these rebel elites do not differ from other rent-seeking elites in power: they require rents in order to address the political, economic and social inequalities that motivated their armed struggle against the central government in the first place (Cederman, Gleditsch and Buhaug 2013). Political office gained through power-sharing provides them with the financial means to do so (Bueno de Mesquita et al. 2003). Rebels can strategically redistribute these resources to their constituencies in exchange for political support. For instance, such preferential resource allocation can take different forms. It can include targeting funds from tax revenue, natural resources and foreign aid through patronage networks to former rebels' own constituencies. Redistribution can also take the form of preferential access to post-conflict reconstruction aid by recipient rebel constituencies. ${ }^{3}$ While the precise form of this targeted investment is likely context specific, preferential redistribution should ultimately manifest itself in uneven patterns of subnational economic development (Hodler and Raschky 2014; Kramon and Posner 2013).

The political pressure to redistribute resources is intensified by the temporal limitation of power-sharing governments. Executive power-sharing - as opposed to most other forms of postconflict institutional arrangements - is often temporally limited as interim governments are replaced by elected governments after a pre-agreed period. Rebels in such temporally limited power-sharing cabinets cannot be certain that they will be represented in the post-interim government, after elections have taken place. The limited time horizon of executive power-sharing adds to elites' incentives to capture as many resources as possible in the present and channel them towards their constituencies to secure political survival in the future (Levi 1989).

\section{Distributing wealth to the periphery}

The key recipient of rebel elites' redistributive strategy are the ethnic support networks established during the course of the civil war. In a large majority of civil wars - especially on the African continent - these support networks are based on ethnic groups. The dense social networks of ethnic groups ensure low-cost access to information about the group members' behavior and preferences (Fearon and Laitin 1996). This information increases trust within the ethnic group and lowers the coordination costs of organizing rebellion. Rebel elites therefore buy support from co-ethnics because it is 'cheaper' than buying it from any other social group. Finally, ideas of within-group solidarity, a shared fate of marginalization through an out-group, as well as shared feelings of territoriality and ethnic 'homelands' provide powerful narratives of identity and, thus, a basis for political mobilization, particularly through ethnic parties (Utas 2012).

Geographically, rebel elites' ethnic favoritism manifests itself in regional favoritism (Hodler and Raschky 2014). This pattern is a function of the territorial dimension of executive powersharing at the political center hypothesized above: ethnic identity in Africa is heavily linked to a group's spatial location within a state (Michalopoulos and Papaioannou 2013). This spatial concentration of ethnic settlements overlaps with weak territorial authority over many of these settlement areas as a result of weak states in Africa (Herbst 2000). Even if elites directly engage in rent capture in the capital, this overlap between ethnic settlement and political as well as geographical distance to the center makes it likely that ethnic favoritism translates into regional resource investment along ethnic lines (De Luca et al. 2018). Accordingly, preferential resource allocation is likely to cluster in the settlement area of a rebel groups' ethnic constituency. Thus our main observable implication is:

\footnotetext{
${ }^{2}$ Accessing state resources through government ministries is not limited to the most powerful cabinet posts. Kramon and Posner $(2016$, 4), for instance, report that a co-ethnic as minister of education has 'an effect roughly comparable to having a co-ethnic president' on citizens' additional years of education.

${ }^{3}$ See Jablonski (2014) on the political role of aid in non-conflict contexts.
} 
Hypothesis 1: Sub-national regions with ethnic constituencies of rebel groups will display higher levels of post-conflict development once rebel elites participate in a power-sharing government, compared to regions without rebel representation in the same period.

\section{Data}

To test our argument empirically, we construct a dataset of African countries between 1992 and 2005 in which a civil war had been concluded with a peace agreement and where the conflict parties implemented executive power-sharing at the national level of government. ${ }^{4}$ We explicitly focus on countries where the civil war did not recur within the first five post-conflict years. This ensures that our estimates of resource allocation after the power-sharing government are not distorted by the recurrence of large-scale violence. Moreover, the power-sharing government itself needs to have lasted at least one year, to ensure that a meaningful amount of resource allocation can take place. For all countries that meet these criteria (see Table 1), we include in our sample three years before the year in which the power-sharing government is implemented and three years after. This allows us to exploit temporal variation in resource investments within these countries.

Our primary unit of observation is the grid cell within these countries. Building on the spatial disaggregation by the PRIO-GRID data set, we use $0.5 \times 0.5$ decimal degree resolution cells; the grid cells are approximately $55 \times 55 \mathrm{~km}$ in size at the equator (Tollefsen, Strand and Buhaug 2012). We choose grid cells as a unit of observation over other possible sub-national units of observation - such as second-level administrative units - because grid cells allow us to use very fine-grained disaggregated data. Given the high spatial resolution of the PRIO-GRID we can precisely distinguish between urbanized and other areas, for instance. This distinction also allows us to test theoretical implications about development patterns within ethnic settlement groups and to exploit the contiguity of cells in robustness checks.

Most importantly, grid cells are drawn artificially. This ensures that they are strictly exogenous to the phenomenon we study. The borders of second-level administrative units or the spatial extent of ethnic settlement areas, by contrast, are drawn based on unobserved historical features, including conflict history. ${ }^{5}$ Thus alternative units of analysis run the risk of being endogenous to the conflict process itself. ${ }^{6}$

\section{Night-time light intensity}

We argue that the redistributive effect of power-sharing manifests itself in more pronounced levels of sub-national economic development in rebels' ethnic constituency areas. We proxy the average development level of a grid cell/year with the intensity of night lights in a given grid cell/year. Night-time light intensity is captured by satellites from the United States Air Force and Defense Meteorological Satellite Program (DMSP) with an Operational Linescan System (OLS). The DMSP-OLS data covers the entire globe, dates back to 1992, and is provided in digital format by the US National Oceanic and Atmospheric Administration (NOAA). The NOAA image processing removes sources other than artificial illumination, such as forest fires

\footnotetext{
${ }^{4}$ We employ the Uppsala Conflict Data Program's definitions of 'civil war' and 'peace agreement' (Gleditsch et al. 2002). The temporal domain is restricted to 1992-2005 as data on night-time light intensity only goes back to 1992 and PSED only covers peace agreements signed between 1989 and 2006. We exclude the peace agreements in Burundi (2000 and 2003) and Djibouti (1994 and 2000) where no geographically distinct ethnic settlement patterns are observable. We also exclude the 2000 peace agreement in the Comoros as it is missing from the EPR data.

${ }^{5}$ In their presentation of the GeoEPR data, Wucherpfennig et al. $(2011,431)$ discuss how their measurement reflects changing settlement areas inter alia due to conflict processes.

${ }^{6}$ Nevertheless, our choice of unit of observation could induce a modifiable area unit problem. In the appendix, we therefore replicate our analysis using a sample of administrative units and ethnic settlement areas as units of observation.
} 
Table 1. Countries and grid cells in the sample

\begin{tabular}{lccccc}
\hline Country & $\begin{array}{c}\text { First year of } \\
\text { power-sharing }\end{array}$ & $\begin{array}{c}\text { Years in } \\
\text { time series }\end{array}$ & $\begin{array}{c}\text { No. grid cells } \\
\text { in country }\end{array}$ & $\begin{array}{c}\text { No. grid cell years } \\
\text { in time series }\end{array}$ & $\begin{array}{c}\text { Rebels in } \\
\text { power-sharing }\end{array}$ \\
\hline Angola & 2003 & $2000-2006$ & 435 & 3,045 & UNITA \\
DRC & 2004 & $2001-2007$ & 763 & 5,341 & MLC, RCD \\
Ivory Coast & 2006 & $2003-2009$ & 113 & 791 & FN \\
Liberia & 2004 & $2001-2007$ & 37 & 259 & LURD, MODEL \\
Mali & 1994 & $1992-1997$ & 426 & 2,556 & MPA \\
Niger & 1999 & $1996-2002$ & 402 & 2,814 & ORA/CRA \\
Sudan & 2006 & $2003-2009$ & 840 & 5,880 & SPLM/A, NDA \\
\hline
\end{tabular}

Note: only five years are included for Mali, since we lack data on night light emissions prior to 1992. UNITA: União Nacional para a Independência Total de Angola; MLC: Mouvement de Libération du Congo, RCD: Rassemblement Congolais pour la Démocratie; FN: Force Nouvelles; LURD: Liberians United for Reconciliation and Democracy, MODEL: Movement for Democracy in Liberia; MPA: Mouvement Populaire de l'Azaouad; ORA/CRA: Coordination of the Armed Resistance/ Armed Resistance Organization; SPLM/A: Sudan People's Liberation Movement/Army; NDA: National Democratic Alliance

or strong moon light. The processed satellite data is combined over an entire year for a land area that approximates $0.86 \times 0.86 \mathrm{~km}$ at the equator. The PRIO-GRID dataset aggregates these pixel values to a $55 \times 55 \mathrm{~km}$ grid. It adjusts the original DMSP-OLS night light pixel intensity for changes in lens sensitivity over time, thereby normalizing the 0 to 63 original scale of light intensity to a value between 0 and 1 (Tollefsen, Strand and Buhaug 2012).

A variety of studies have used satellite imagery of night light emissions to capture subnational variation in development; it has been reported to correlate highly with sub-national levels of GDP (Min 2015; Weidmann and Schutte 2017). One advantage of using night lights to proxy for resource allocation is that it is independent of political interference and imprecise measurement through national statistical offices. Prior research has also shown that satellite imagery of night light emissions is uniquely suited to detect electrification, even in areas that are characterized by very low levels of overall electrification such as rural Africa (Min et al. 2013).

As the availability of electricity reflects economic development more broadly, night lights capture a wide range of economic outcomes that can result from preferential political treatment in post-conflict states (Henderson, Storeygard and Weil 2012; Weidmann and Schutte 2017). The first outcome of resource redistribution captured by night lights is electricity itself. In economies devastated by civil conflict, as in any state in the developing and developed world, access to electricity 'is a life-altering transformation that improves welfare' (Min 2015, 2). Other investments reflected by night lights, however, likely depend on the political economy of respective country contexts. In the Democratic Republic of the Congo, for instance, diamond, gold, copper and col$\tan$ mining was a substantial income source of rebel groups during the conflict. As a consequence, resource redistribution through power-sharing often took the form of preferential concessions grants to exploit resources in areas that rebels still controlled (Global Witness 2006). In other contexts, differences in night lights might reflect differential access to post-conflict reconstruction projects, which is often shaped by the politics of (formerly) armed groups (Parks, Colletta and Oppenheim 2013). Night lights serve as a useful proxy for the changes in economic productivity as a result of these different types of political preferential treatment.

\section{Power-sharing governments}

Our theoretical argument rests on the assumption that rebel groups preferentially steer resources to their ethnic constituency groups. We define a rebel group's ethnic constituency as ethnic groups from which a rebel group has recruited, to which it made any claim to fight on its behalf, or from which it received substantial political support during the civil war (Wucherpfennig et al. 2012). Examples of such rebel constituencies include the Dinka in Southern Sudan which formed 
the main support group for SPLA leader John Garang (and his successor Salva Kiir Mayardit), the Mandingo and Krahn communities that supported LURD and MODEL during the later stages of the Liberian civil war and the Angolan Ovimbundu-Ovambo which backed UNITA's Jonas Savimbi.

To empirically identify these rebel constituencies for the seven countries in our sample, we combine data from the PSED with information on rebels' ethnic affiliations and the sub-national settlement patterns of ethnic groups from the EPR project (Ottmann and Vüllers 2015; Vogt et al. 2015). In a first step, we use PSED to identify when a particular rebel group gained access to ministry positions in a joint power-sharing government following a civil war. The PSED also provides information on the overall number of portfolios held by these rebel elites in the power-sharing government and the exact type of each portfolio. In total, rebels held fifty-nine distinct portfolios over time in the countries in our sample. The number of portfolios in a single power-sharing government varies from a minimum of one (Niger) to a maximum of twelve (Sudan).

We then match the data on rebel groups in power-sharing arrangements to the list of rebels' ethnic affiliations provided by the ACD2EPR data collection (Wucherpfennig et al. 2012). This link allows us to use data on the sub-national settlement patterns of all ethnic groups to identify the geographic location of constituencies that support rebel elites in power-sharing governments (Vogt et al. 2015). There are fifty-five distinct ethnic groups in our sample. Of these, nineteen are represented by rebel groups participating in power-sharing governments. Thirteen are linked to ethnic groups which are represented in the government without being linked to a rebel group. Twenty-three ethnic groups have no representation at the national level through either government or rebel actors.

Combining PSED and EPR in this way enables us to create our main independent variable Representation in Executive Power Sharing. This dummy-coded variable measures whether a grid cell is inhabited by one or more ethnic groups that have a link to a rebel group that is represented in the power-sharing government.

\section{Descriptive evidence}

Figure 2 offers descriptive evidence in line with our argument. The left panel plots the geographical distribution of rebels' and the government's constituency groups according to the settlement of their ethnic support groups. The right panel plots the presence of a night light increase between the first full year in which the power-sharing government was in place and two years later.

Figure 2 displays substantial variation and considerable geographic variation in the settlement patterns of rebels' ethnic support groups. In some cases, the extent of these constituency areas is driven by rebels' links to numerous ethnic groups with locally concentrated settlement regions, such as in Sudan. In other cases, for example UNITA in Angola, the geographic extent of rebel groups' ethnic settlement patterns is a function of a single relatively homogeneous group, in this case the Ovimbundu-Ovambo. We also observe a visible overlap in night light increases and rebel constituency areas.

We also find indicative evidence for our postulated redistributive mechanism at the sub-national level. Consider the example of the Ivory Coast. In 2005, after repeated attempts to pacify the conflict between the Force Nouvelles (FN) rebels from the northern part of the country and the government in the south, the two sides agreed to set up a wide-ranging power-sharing government. The FN rebels - an umbrella group that subsumed a number of Ivorian rebel outfits - received a total of six minister positions. One of these minister positions, the ministry of sports, was given to Michel Gueu, a military commander in the MPCI rebel group which was part of the FN.

In 2008, with the FN still participating in the power-sharing government (even though Gueu had become army inspector of the FN in the meantime), Gueu sketched the political and economic agenda of the FN: 


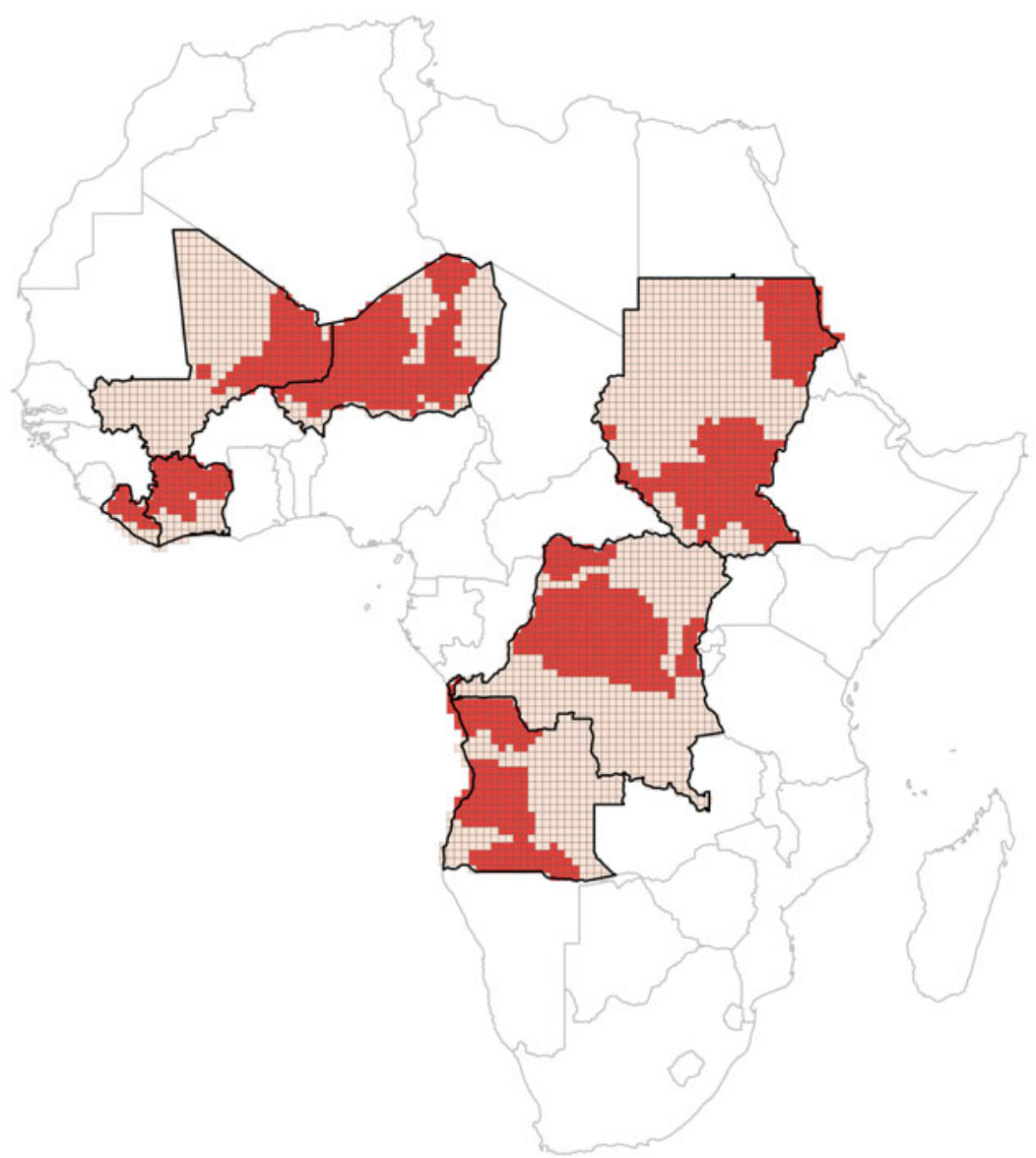

Rebels' ethnic constituency area

No Yes

Figure 2. Rebel constituencies and night lights

I take, for instance, the case of the region of Binhouye. You know that from Zouan-Hounien to Bloléquin via Binhouye the route section is not asphalted and I suppose that our executives, especially our elected representatives, will ask the President of the Republic to have this route section asphalted which is estimated at 100 and $150 \mathrm{~km}$ at most. And when we know that the road precedes development, I think this is also a boost that we will give to the development of our different regions (Louamy 2008, n.p.).

The quote illustrates that it was the FN's participation at the executive level - the power-sharing government - that enabled it to petition the president to steer development resources to the region of Binhouye. Indeed, we observe an increase in night light emissions in Binhouye during the power-sharing government. The upper panel of Figure 3 plots Binhouye - which is located in the constituency area of the FN rebels - and the surrounding cities. Between 2004 and 2008, the 


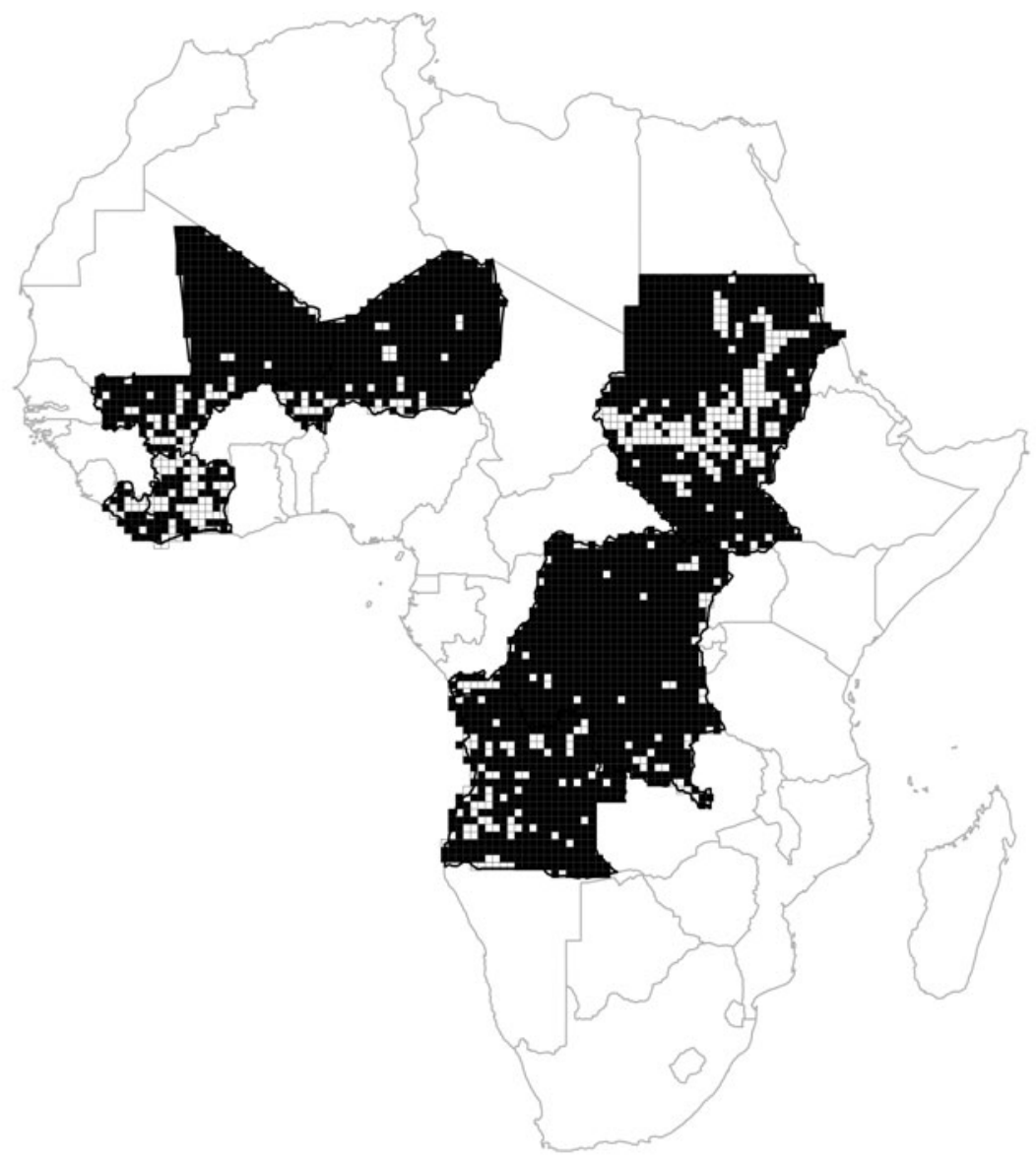

Night lights two years

after start of power sharing

No increase

Increase

Figure 2. Continued.

plot indicates a visible increase in light emissions in Binhouye itself and in the neighbouring city Zouan-Hounien.

Our data also indicate that the redistributive mechanism follows ethnic lines. Consider the example of the Democratic Republic of the Congo, where, during its 1998-2003 civil war:

[...] control of the DRC's Equateur province was divided. Jean-Pierre Bemba's MLC held the northern part [...]. Bemba's family towns, Gbadolite and Gemena, became the rebel headquarters. [...] Kabila's Kinshasa government controlled the southern half of the province. It is no coincidence that this Maginot line between north and south also largely mirrored the ethnic divisions between Ngwaka and others in the north (Bemba's ethnic parentage [...]) and southern Equateur, which is largely ethnically Mongo.

[...] The fact that Bemba was seen as a [...] son of the land greatly advantaged the [MLC] 


\section{Binhouye, Cote d'Ivoire}
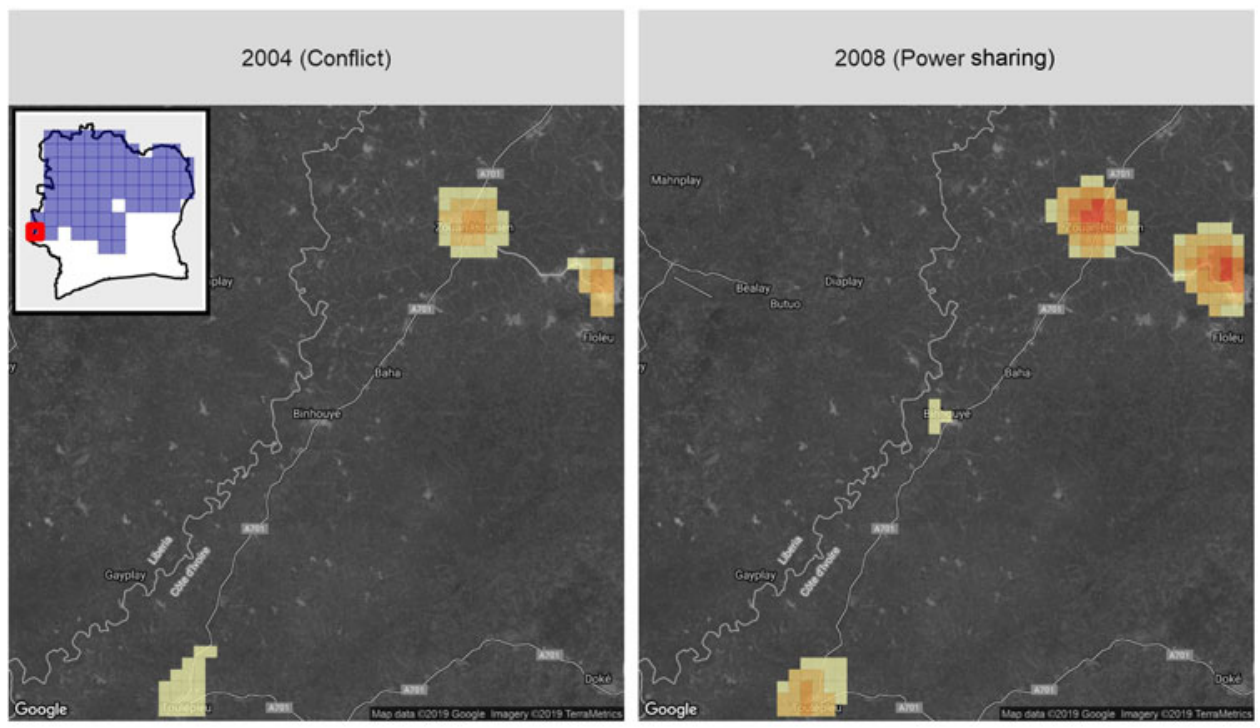

\section{Gbadolite, Democratic Republic of the Congo}
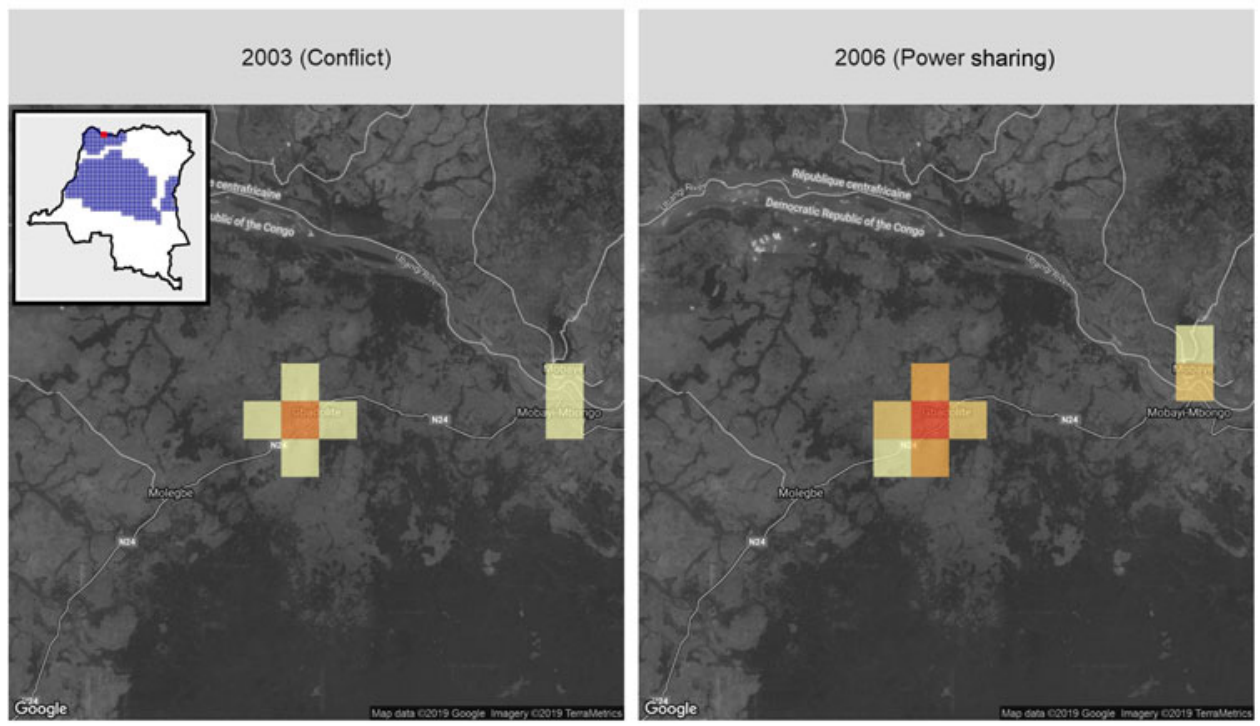

Figure 3. Night lights and constituency regions

Note: the plot compares night light emissions in rebel ethnic constituency areas in Ivory Coast and the Democratic Republic of the Congo. A darker red/yellow indicates higher night lights emissions. The red/dark grid cell in the inset map indicates the location of the displayed areas in relation to the rest of the countries. The shaded blue-filled areas in the inset map represent the rebels' constituency areas.

movement in the early years of the war. [...] During the war, as soon as a town or village fell to the MLC, the rebel movement would set up a local administrative structure consisting of an executive branch of the MLC, a territorial council [...] and a territorial assembly (Carayannis and Lombard 2015, 256-257). 
This ethno-administrative governance structure during the war likely casts a shadow over the structure of post-conflict preferential treatment. Indeed, if we examine the satellite emissions of night lights in Gbadolite, the location of the MLC's headquarters and the Bemba's family town, we observe a visible increase in emissions between the conflict and power-sharing periods (see lower panel of Figure 3).

\section{Econometric strategy}

Since unobserved confounders might render these patterns based on descriptive evidence spurious, we also run a multivariate analysis. The main problem with simply comparing night lights in grid cells that are represented in the central power-sharing coalition to those that are not stems from the heterogeneity of these geographical units. It is plausible to assume that any observed differences in light emissions are (at least in part) driven by, for instance, degree of urbanization, remoteness from the regional capital and/or borders, population size or level of destruction during the civil war. To address this problem, we exploit the temporal structure of our data set. Specifically, we estimate a model of the following form:

$$
N L_{i t+1}=\beta_{1} \text { Representation in Executive Power-Sharing }{ }_{i t}+\beta_{2} \mathrm{X}_{i t}+\gamma_{i}+\eta_{t}+\varepsilon_{i t}
$$

We expect $\beta_{1}$ to be positive, indicating that grid cells have higher night light emissions when they are represented in executive power-sharing. Including grid cell fixed effects - denoted by $\gamma_{i}$ in Equation 1 - allows us to only use over-time variation within a given cell. $\gamma_{i}$ strips the results of all potential time-invariant unobserved confounders on a grid cell level, such as geography or history. This enables us to statistically construct a natural comparison group for each grid cell, namely the same cell at different points in time, and trace the representation status of each grid cell over time. Importantly, $\gamma_{i}$ also controls for whether a group is inhabited by groups with ethnic links to the government as opposed to the rebels, since, unlike rebel representation, this link does not vary over time. Adding a full set of country-year dummies, $\eta_{t}$, controls for country- and time-specific shocks that are common to conflict-to-peace transitions, such as anticipatory effects by rebels and governments prior to the implementation of a peace agreement, peace dividends or aid spikes in years after a conflict has ended. ${ }^{7}$

Set up this way, Equation 1 represents a dynamic difference-in-differences design. We compare before and after power-sharing variation in night lights (first difference) with variation across represented and non-represented grid cells (second difference). Under the assumption of common trends in night light emissions prior to the 'treatment' of power-sharing, the coefficient $\beta_{1}$ in Equation 1 equals the average treatment effect of Representation in Executive Power Sharing on night light emissions. The common trends assumption establishes the counterfactual scenario from which we can draw our causal inference: without the treatment (the representation of a grid cell's ethnic groups in the power-sharing government) the trend in night light emissions would have been similar across treated and untreated grid cells. The treatment induces a deviation from this common trend, approximating the causal effect of the treatment. ${ }^{8}$

However, this common-trends assumption is conditional on other time-varying variables. It is plausible that, for instance, population changes over time or differential ending of battle violence can distort grid-cell-specific trends. To adjust for this possibility, we include a vector of timevarying control variables $X_{i t}$ in Equation 1 . These control variables include measures of population size and violence.

\footnotetext{
${ }^{7}$ Since autocorrelation is a potential problem in this setup, we report clustered standard errors at the grid cell level. Moreover, we use a one-year lead of (logged) night lights at $t+1$ as the dependent variable to avoid simultaneity bias.

${ }^{8}$ We explore the common-trends assumption graphically in the appendix and find that night light trends prior to the establishment of the power-sharing government are likely to be conditional on covariates.
} 
Population size accounts for the possibility that people might move out of ethnic settlement areas in response to violence or repopulate regions from which they previously fled, which might then appear as a correlation between rebel constituency areas and night light emissions. Our population measure is taken from the gridded population of the world data set as included in the PRIO GRID data (CIESIN 2005). ${ }^{9}$ Regions that have experienced higher levels of civil war violence might be more likely to receive a peace dividend as humanitarian aid flows increase, infrastructure is rebuilt and refugees return to their homes. Rebel elites, for instance, might have to reward the communities that suffered the most for their support during the conflict. Such cells might therefore experience increases in night-time light intensity. Consequently, we control for the cumulative sums of Past Battle Fatalities and Past Non-State Fatalities (Sundberg and Melander 2013). ${ }^{10}$

\section{Results}

We report the results of estimating Equation 1 in Table 2. The first model of Table 2 represents a baseline model with only grid cell fixed effects. The second column adds a full set of country-year dummies to account for country- and time-specific annual shocks. Model 3 adds the time-varying covariates. Model 4 additionally controls for a lagged dependent variable to account for reverse causality and additional dynamics in regional investment patterns. ${ }^{11}$ Models 5 and 6 explore our main results using different comparison groups.

Across all models in Table 2, the coefficient for Representation in Executive Power Sharing is positive and statistically significant, even though the coefficient becomes smaller as country-year fixed effects are added. Overall, the results are consistent with our theoretical expectations. As an ethnic group in a grid cell becomes represented in the power-sharing government, the grid cell's night light emissions increase as well.

Models 1-4 establish this increase in comparison to all other ethnic groups in a post-conflict country. This approach helps us to identify a baseline average effect, which we use for the subsequent mechanism, placebo and robustness tests. It masks, however, if the effect differs when the control is comprised either of only groups that remain excluded even once the power-sharing government is established (Model 5), or of only non-rebel constituency groups that were included in the governing coalition before and during the power-sharing government (Model 6).

Making this control group distinction explicit allows us to test if our results are simply driven by control group trends. The positive coefficient for power-sharing representation might reflect the fact that the establishment of a power-sharing government makes already excluded groups worse off. However, the results of Model 5 in Table 2 reject this alternative explanation. The coefficient for power-sharing representation is smaller in Model 5 than in Models 1-4, but is still positive and statistically different from zero. This implies that excluded groups also benefit from the end of a conflict - but to a lesser extent than groups included in the power-sharing government, whose elites can access and redistribute resources from the center.

We can also use the control group distinction to test whether rebel representation in powersharing makes not only newly represented areas better off, but also if it makes groups that are already included in the governing coalition worse off. This would provide additional evidence of the economic component of our power-sharing theory. If power-sharing is indeed about rebels redirecting funds from a common, zero-sum 'government pie', this redistribution should come at the cost of already included groups. The coefficient of Model 6 provides additional evidence to

\footnotetext{
${ }^{9}$ The data are available in 5-year intervals, starting from 1990 . We linearly interpolate the intermediate years.

${ }^{10}$ Ideally, we would also control directly for the presence of peacekeepers as a proxy for sub-national international engagement. However, spatially disaggregated data on peacekeeping only exists for a limited number of cases and time periods that do not completely overlap with our geographic and temporal scope (Ruggeri, Dorussen and Gizelis 2018).

${ }^{11}$ We exclude a lagged dependent variable from the rest of our models since it can induce Nickell (1981) bias.
} 
Table 2. Effect of representation in executive power-sharing on night light emissions in constituency regions

\begin{tabular}{|c|c|c|c|c|c|c|}
\hline & \multicolumn{6}{|c|}{ Dependent variable: Night Lights $_{t+1}(\log )$} \\
\hline & 1 & 2 & 3 & 4 & 5 & 6 \\
\hline Representation in Power Sharing & $\begin{array}{c}0.192^{\star \star \star} \\
(0.005)\end{array}$ & $\begin{array}{c}0.007^{\star \star \star} \\
(0.001)\end{array}$ & $\begin{array}{c}0.007^{\star \star \star} \\
(0.001)\end{array}$ & $\begin{array}{c}0.006^{\star \star \star} \\
(0.001)\end{array}$ & $\begin{array}{l}0.002^{\star} \\
(0.001)\end{array}$ & $\begin{array}{l}0.014^{\star \star} \\
(0.006)\end{array}$ \\
\hline Population (log) & & & $\begin{array}{c}0.067^{\star \star} \\
(0.027)\end{array}$ & $\begin{array}{l}0.067^{\star \star} \\
(0.034)\end{array}$ & $\begin{array}{c}0.017 \\
(0.013)\end{array}$ & $\begin{array}{c}0.024 \\
(0.016)\end{array}$ \\
\hline Past Battle Fatalities (log) & & & $\begin{array}{c}-0.0001 \\
(0.001)\end{array}$ & $\begin{array}{l}0.0002 \\
(0.001)\end{array}$ & $\begin{array}{c}0.001 \\
(0.001)\end{array}$ & $\begin{array}{c}0.001 \\
(0.002)\end{array}$ \\
\hline Past Non-State Fatalities (log) & & & $\begin{array}{l}-0.001 \\
(0.001)\end{array}$ & $\begin{array}{c}-0.0005 \\
(0.001)\end{array}$ & $\begin{array}{l}-0.001 \\
(0.001)\end{array}$ & $\begin{array}{c}0.001 \\
(0.001)\end{array}$ \\
\hline Night Lights $_{t-1}(\log )$ & & & & $\begin{array}{l}0.250^{\star *} \\
(0.114)\end{array}$ & & \\
\hline Grid-cell FE & Yes & Yes & Yes & Yes & Yes & Yes \\
\hline Country-Year FE & - & Yes & Yes & Yes & Yes & Yes \\
\hline Control Group & All & All & All & All & Excluded & Included \\
\hline Observations & 20,686 & 20,686 & 20,686 & 20,260 & 16,160 & 9,804 \\
\hline Adjusted $R^{2}$ & 0.503 & 0.993 & 0.993 & 0.993 & 0.995 & 0.994 \\
\hline
\end{tabular}

Note: robust standard errors clustered on grid cells are reported in parentheses. ${ }^{\star} p<0.1 ;{ }^{\star \star} p<0.05 ;{ }^{\star \star \star} p<0.01$

support this argument. It is positive, statistically significant and larger than the coefficient of Models 1-5. This implies that formerly excluded ethnic groups benefit from power-sharing through rebel elites, while already included groups simultaneously become worse off.

\section{Substantive effects}

The exotic nature of our dependent variable makes it difficult to get a sense of the effect size from the raw coefficients. ${ }^{12}$ To estimate the substantive effect size of our findings, we exploit the fact that night lights can be used to predict local wealth (Weidmann and Schutte 2017). Following prior studies, we express the effects of executive power-sharing on night light emissions as a percent of local GDP (Henderson, Storeygard and Weil 2012; Hodler and Raschky 2014). ${ }^{13}$ We find that the effect of Representation in Executive Power Sharing - as estimated in Model 3 - corresponds to a 0.91 per cent increase in gross-cell product. This means that grid cells with an ethnic group represented by rebels in a power-sharing government have, on average, a regional GDP that is about 1 per cent higher than the regional GDP of other grid cells based on their night light increase.

While this effect size might seem small at first, we believe it is reasonable for two reasons. First, it is to be expected theoretically. Night light emissions proxy for a variety of resources, such as infrastructure and electricity, but they are not the only resources that elites in power-sharing governments can allocate (Kramon and Posner 2013). Even if power-sharing has a strong net redistributive effect, our data can only capture the effect reflected in night lights. This makes night light increases a conservative estimate of the net redistributive effect, which is thus likely to be small overall. Secondly, our finding is of a similar magnitude as other findings on the effects of distributive politics on night light emissions. Hodler and Raschky $(2014,1013)$ report that subnational regions from which a country's political leader originates experience an increase in local GDP by about 1.3 per cent.

\footnotetext{
${ }^{12}$ Moreover, and similar to other studies that have used night lights to measure economic development (see, for example, Henderson, Storeygard and Weil 2012), a large part of the explained variation in our dependent variable stems from the grid cell and country-year fixed effects: model diagnostics indicate that about 47 per cent of the $R^{2}$ can be attributed to differences between grid cells, and another approximately 40 per cent is attributable to over-time variation. However, $R^{2}$ is not a good indicator of model fit or of the explanatory power of our main independent variable (King 1986, 675ff). We therefore complement our analysis with out-of-sample predictions below.

${ }^{13}$ We describe the calculation in the online appendix.
} 
To compare this effect size to other variables, and to account for the potentially misleading predictive accuracy of the $R^{2}$ in our models, we perform an out-of-sample prediction exercise using 10 -fold cross-validation. To assess the relative importance of our power-sharing dummy, we include common correlates of night light emissions in this predictive model (Henderson, Storeygard and Weil 2012; Weidmann and Schutte 2017). ${ }^{14}$ In contrast to the explanatory approach employed so far, the goal of this exercise is not to isolate the effect of representation in power-sharing from potential confounders. Rather, it answers the following questions: How useful is it to know that a grid cell is represented in the power-sharing government to predict the levels of night light emissions? How useful is this knowledge compared to other predictors of night lights?

To answer these questions, Figure 4 plots the importance of each variable in predicting night lights from grid-cell-level information. The lagged dependent variable and population are revealed to be the most important predictors. This is not surprising. Economic development is sluggish, suggesting strong autocorrelation, while population levels have been found to be one of the strongest predictors of night light emissions in general (Henderson, Storeygard and Weil 2012). Nevertheless, the power-sharing dummy emerges as the third-most important variable in the cross-validation model. This means that to predict night lights using grid-cell-level information, it is more useful to know that a cell was ethnically represented by rebels in the power-sharing executive than to know the cell's urbanization level, its petroleum deposits or its distance to the capital. We interpret this as additional evidence that the effect of power-sharing, while small, is still substantively important.

\section{Type and duration of power-sharing governments}

The difference-in-differences strategy guards against a wide range of potential confounders of the relationship between power-sharing and night lights. Since we cannot find a source of strictly exogenous variation for power-sharing, however, concerns remain about unobserved variables that might bias this relationship. We therefore complement our main analysis with evidence of additional implications of the theory (Rosenbaum 2002, 5f).

In a first step, we investigate if night lights vary with the type of power-sharing in theoretically expected ways. Our argument emphasizes the effects of elite access to state funds through participation in post-conflict cabinets. Rebel elites might be better able to channel funds towards their political supporters if they possess sufficient political power to do so. We should therefore observe a stronger pattern if we examine night lights in constituency regions when rebel elites hold more powerful positions. We add Representation in Executive Power Sharing (Senior Portfolios) to Equation 1 to measure whether a grid cell is inhabited by ethnic groups linked to a rebel group that occupies politically powerful cabinet portfolios. ${ }^{15}$

In addition to political power, resource allocation to supporters might be a function of rebel elites explicitly controlling economic resources. A second dummy variable - Representation in Executive Power Sharing (Economic Portfolios) - consequently captures whether an ethnic group has links to rebels occupying portfolios managing the post-conflict country's economy, resources or infrastructure. ${ }^{16}$

Finally, we also test how the nature of the link between rebel elites and their constituencies affects night light intensity. We would expect constituencies closer to the rebel leadership to

\footnotetext{
${ }^{14} \mathrm{We}$ discuss the details of this cross-validation exercise in the online appendix.

${ }^{15}$ We define the following cabinet portfolios as politically powerful: vice president, prime minister, foreign affairs, justice, defense, interior and finance.

${ }^{16}$ Please consult the online appendix for a detailed overview of cabinet portfolios held by rebel elites and their classification into these categories.
} 
Figure 4. Predictive performance from cross-validation models Note: variable importance scores based on t-statistics from a 10-fold crossvalidation linear regression model with 15 test/training splits.

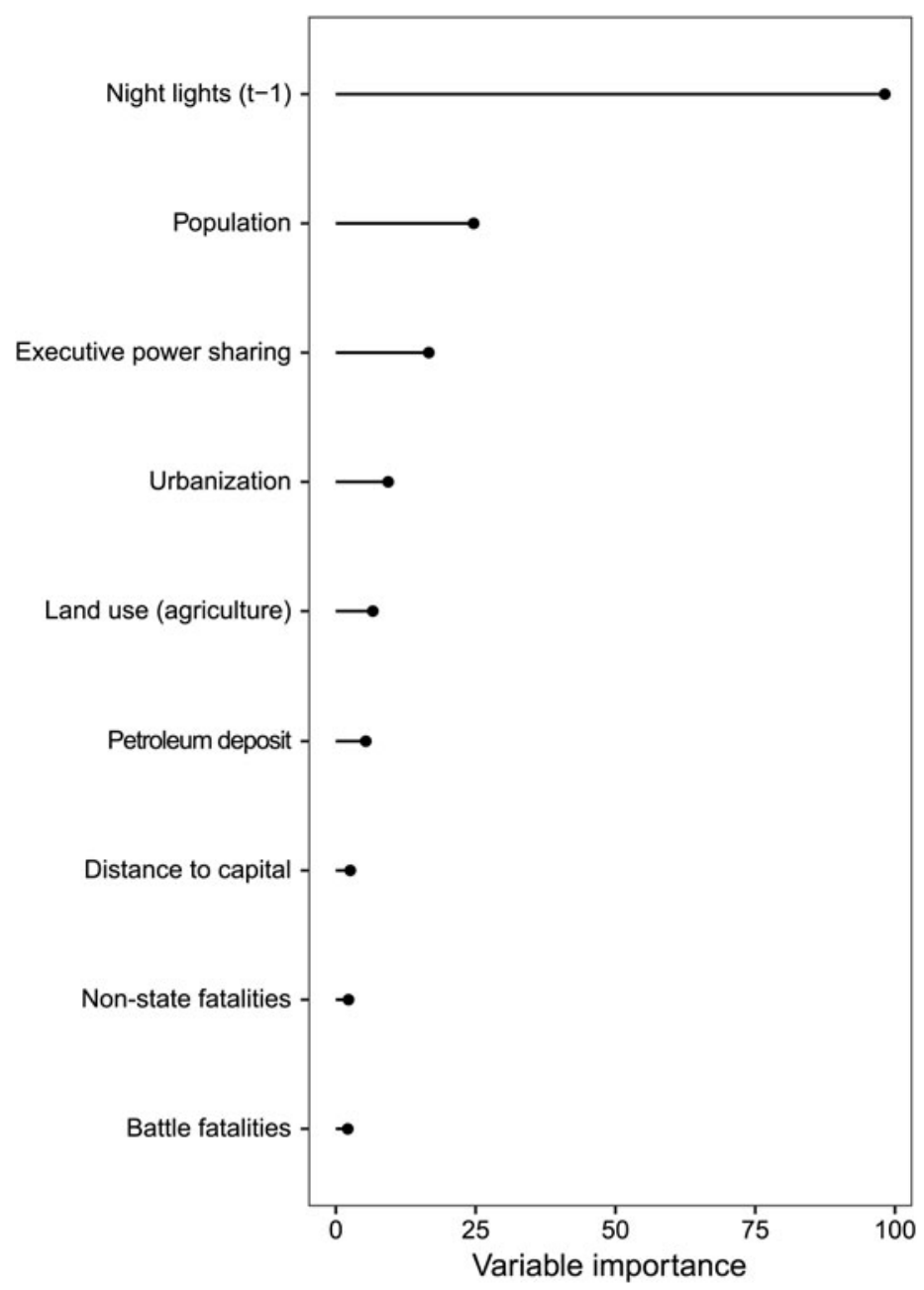

receive more resources, as they are more reliable providers of political support. Data on rebel leaders' ethnic affiliations therefore informs the dummy variable Representation in Executive Power Sharing (Leadership Constituency) (Ottmann 2012). It considers only grid cells inhabited by ethnic groups represented in power-sharing governments when the rebel leader is a member of the same ethnic group.

In Figure 5 we report the results of these additional regressions. The plot shows coefficient estimates - based on equivalents of Model 3 in Table 2 - for each variable with varying leads of the dependent variable. Across specifications, the results are consistent with our expectations. We find the strongest effect for grid cells populated by co-ethnics of a rebel leader. With coefficients between 0.011 and 0.06 the effect is almost twice as large as in our main models, providing further evidence of a redistributive effect of power-sharing governments.

The temporary nature of power-sharing and night lights as slow-moving resource investments allows us to test another theoretical implication. Power-sharing governments are typically interim institutions, often with explicit sunset clauses, established as part of a peace deal until more 


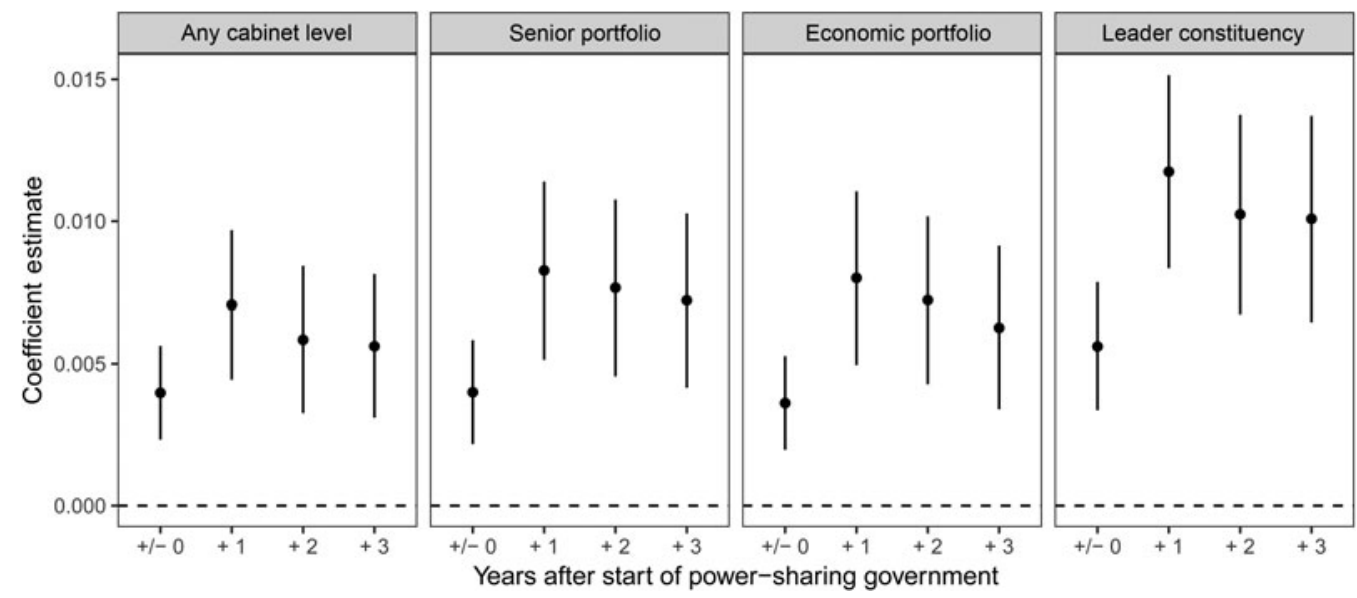

Figure 5. Minister portfolios, constituency type and night light emissions over time Note: the left panel corresponds to Model 3 in Table 2 with varying leads of the dependent variable. The other panels represent model estimates where the Power-Sharing coefficient is replaced with the labelled variable. 95 per cent confidence intervals shown.

long-term steps towards peace can be taken. ${ }^{17}$ This temporary nature of the institution implies that access to state resources ends if rebels do not manage to remain in power. As funding for infrastructure dries up and maintenance becomes more difficult, we expect the effect of regional representation in power-sharing to dissipate over time. At the same time, night light investments require some time to take effect. Thus, any effect is likely to be more pronounced only after some time following the implementation of the power-sharing government.

Figure 5 also allows us to test both propositions. In addition to the different types of powersharing, it displays the coefficient when we measure the dependent variable at different points in the future. Consistent with our expectations, we observe that the effect is only small in the first year, becomes largest in the second year and dissipates slowly over time. ${ }^{18}$

\section{Constituency characteristics}

While the previous tests have attempted to establish that post-conflict night light improvements are indeed attributable to rebel participation in government, it is still difficult to assess whether this result is indeed driven by redistribution. To generate implications that allow us to test this redistributive mechanism more directly, we turn to the literature on public goods provision in ethnically heterogeneous societies. This literature has established that public goods provision in ethnically diverse locations tends to be lower (Ejdemyr, Kramon and Robinson 2018; Tajima, Samphantharak and Ostwald 2018). It is difficult for elites, the argument goes, to identify who will profit from resource allocation if both constituency and non-constituency groups occupy the same area.

We would expect this pattern to be even more pronounced in post-conflict settings: in contexts with a history of extreme intergroup ethnic violence, elites are unlikely to direct resources to areas

\footnotetext{
${ }^{17}$ In some cases, power-sharing cabinets where some groups receive specific ethnic quotas become part of a permanent solution, enshrined in the constitution. In the countries we study, all power-sharing governments ended within three years. The exception is Sudan, where the power-sharing government in Khartoum ended with the independence of South Sudan in 2011.

${ }^{18}$ In the Appendix, we test the idea of night light variation with the end of power-sharing more formally. The results are consistent with our expectation: once power-sharing ends, coefficients that capture night light emissions in constituency regions drop in size and become statistically insignificant.
} 
Figure 6. Night light emissions in constituency areas with varying numbers of ethnic groups

Note: marginal effect of Representation in Executive Power-Sharing at varying numbers of ethnic groups per grid cell. Models include grid cell and country-year fixed effects. 95 per cent confidence intervals shown.

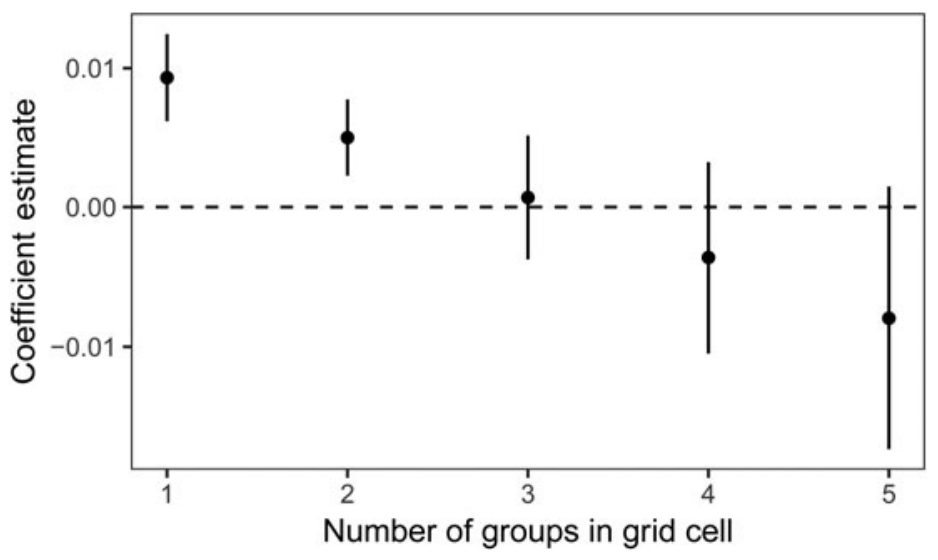

where these goods could end up benefiting groups that were involved in violence against their own group. We should therefore observe that night light emissions are particularly high in areas where elites can clearly identify constituencies, for instance in grid cells where only one or very few groups settle simultaneously.

Figure 6 displays the marginal of effect of power-sharing on night light emissions, based on an interaction between our power-sharing dummy variable and the number of ethnic groups in a grid cell. The pattern suggests that the effect of a grid cell's power-sharing representation is most visible when the number of groups in a cell is low. The effect notably declines and becomes negative - albeit statistically insignificant - as the number of groups in a cell increases. This provides reassuring evidence that a political redistribution effect is indeed at work in which elites target resources based on the observable number of groups in the recipient location.

\section{Robustness tests}

In the appendix, we present a number of additional robustness tests. First, we replicate our analysis using different geographical units to account for the possibility of a modifiable area unit problem. We also account for spatial dependency through spatially robust standard errors. Secondly, we replicate our main model using only geographically matched grid cells just inside or outside an ethnic group's settlement area in order to account for unobserved heterogeneity across observations. Thirdly, we explore whether the effect of power-sharing dissipates over time and whether it represents a reversion to ex ante economic activity. Finally, we conduct a placebo test to ascertain whether the reported effects are indeed attributable to the representation in executive power-sharing and not to peace agreements more broadly. Across all models, our substantive results hold.

\section{Conclusion}

In this article, we examine the relationship between post-conflict power-sharing, state revenues and resource redistribution in Africa. We put forward the idea that power-sharing governments represent a unique opportunity for rebel elites to generate revenue from state resources. Modeling rebel elites as rent- and office-seeking agents implies that power-sharing governments should preferentially redistribute resources to sub-national regions that harbor ethnic constituents of the rebels in the central power-sharing government. We argue that such preferential resource allocation is observable as an increase in electrification, detectable through the emission of electricitypowered light during the nighttime. 
Across a wide range of statistical models, we are able to show that grid cells inhabited by ethnic groups with representation by a rebel group in a power-sharing government exhibit higher night light emissions than grid cells without this representation. We interpret this pattern as an empirical expression of the fact that executive-level power-sharing in Africa has a genuine territorial and economic dimension.

We focus on African post-conflict countries and are careful not to generalize beyond this continent. Future work should therefore investigate more closely the relationship between powersharing and resource redistribution in other parts of the world. Empirically, such work would benefit from more refined measures of redistribution. While our night light measure can capture a wide range of political goods, such as infrastructure investments that are reflected in increased electrification, it is oblivious to other patronage resources, such as jobs or preferential access to post-conflict aid that is not directly reflected in economic development (for example, schooling or health aid). Another limitation of this study is its somewhat imprecise measurement of ethnic settlement areas, especially in ethnically heterogeneous areas. Future research should invest in individual-level survey data on ethnicity, rebel affiliation and redistribution to shed light on the precise micro-level mechanisms underlying the results documented in this article.

This notwithstanding, our political economy approach injects new life into the established research program on the effects of power-sharing on post-conflict peace. Prior research has emphasized the allocation of decision-making rights or the distribution of spoils among elites in power-sharing arrangements. In an attempt to integrate these approaches with research on distributive politics, we shift the perspective towards redistribution among former rebel elites and their constituencies. Whether or not successful redistribution changes both objective and perceived group grievances - and thus reduces the probability of renewed conflict - remains an exciting avenue for future studies.

Supplementary material. Data replication sets are available at: https://doi.org/10.7910/DVN/3RF1X0 and online appendices are available at https://doi.org/10.1017/S0007123419000474.

Acknowledgements. We thank Konstantin Ash, Kristin Bakke, Matthijs Bogaards, Inken von Borzyskowski, Jessica Maves Braithwaite, Caroline Brandt, Sabine Carey, Niheer Dasandi, Natalia Garbiras-Díaz, Izmene Gizelis, Christian Glaessel, Belén Gonzalez, Kristen Angela Harkness, Caroline Hartzell, Havard Hegre, Matthew Hoddie, Alexander De Juan, Nick Lemay-Hebert, Mathis Lohaus, Cameron Mailhot, Aila Matanock, Andreas Mehler, Mansoob Murshed, Matthew Nanes, Suda Perera, Caryn Pfeiffer, Lindsay Reid, Kit Rickard, Adam Scharpf, and Stefan Wolff as well as participants at ECPR, ISA, and IPSA conventions for helpful comments and discussions. We also thank the editor Thomas Böhmelt and two anonymous referees for excellent and constructive feedback. We acknowledge support from the German Research Foundation (OT 494/1-1, ME 1701/7-1). The authors are listed in alphabetical order. Equal authorship is implied. The data, replication instructions and the data codebook can be found at https://doi.org/10.7910/DVN/3RF1X0.

\section{References}

Acemoglu D and Robinson JA (2000) Why did the West extend the franchise? Democracy, inequality, and growth in historical perspective. The Quarterly Journal of Economics 115(4), 1167-1199.

Arriola LR (2009) Patronage and political stability in Africa. Comparative Political Studies 42(10), 1339-1362.

Bakke KM (2015) Decentralization and Intrastate Struggles. Cambridge: Cambridge University Press.

Bates R (2008) When Things Fell Apart. State Failure in Late-Century Africa. Cambridge: Cambridge University Press.

Binningsbo HM and Rustad SA (2012) Sharing the wealth: a pathway to peace or a trail to nowhere? Conflict Management and Peace Science 29(5), 547-566.

Boone C (2003) Political Topographies of the African State: Territorial Authority and Institutional Choice. Cambridge: Cambridge University Press.

Bueno de Mesquita B et al. (2003) The Logic of Political Survival. Cambridge, MA: MIT Press.

Carayannis T and Lombard L (2015) Making Sense of the Central African Republic. London: Zed Books.

Cederman L-E, Gleditsch KS and Buhaug H (2013) Inequality, Grievances, and Civil War. Cambridge: Cambridge University Press.

CIESIN (2005) Gridded Population of the World, Version 3 (GPWv3): Population Count Grid. Center for International Earth Science Information Network: Palisades, NY: NASA Socioeconomic Data and Applications Center (SEDAC). 
Dal Bó E and Powell R (2009) A model of spoils politics. American Journal of Political Science 53(1), $207-222$.

De Luca G et al. (2018) Ethnic favoritism: an axiom of politics? Journal of Development Economics 132, 115-129.

Ejdemyr S, Kramon E and Robinson AL (2018) Segregation, ethnic favoritism, and the strategic targeting of local public goods. Comparative Political Studies 51(9), 1111-1143.

Fearon JD and Laitin DD (1996) Explaining interethnic cooperation. American Political Science Review 90(4), $715-735$.

Francois P, Rainer I and Trebbi F (2015) How is power shared in Africa? Econometrica 83(2), 465-503.

Gates S et al. (2016) Power sharing, protection, and peace. Journal of Politics 78(2), 512-526.

Gleditsch NP et al. (2002) Armed conflict 1946-2011: a new dataset. Journal of Peace Research 39(5), 615-637.

Global Witness (2006) Under-Mining Peace: The Explosive Trade in Casserite in Eastern DRC. Available from https://www. globalwitness.org/sites/default/files/pdfs/under-mining|\%20peace.pdf (accessed 13 May 2019).

Golden M and Min B (2013) Distributive politics around the world. Annual Review of Political Science 16(1), 73-99.

Hartzell C and Hoddie M (2003) Institutionalizing peace: power sharing and post-civil War conflict management. American Journal of Political Science 47(2), 318-332.

Haass F and Ottmann M (2019) Replication data for: rebels, revenue, and redistribution: the political geography of post-conflict power-sharing in Africa. https://doi.org/10.7910/DVN/3RF1X0, Harvard Dataverse, V1.

Henderson JV, Storeygard A and Weil DN (2012) Measuring economic growth from outer space. American Economic Review 102(2), 994-1028.

Herbst J (2000) States and Power in Africa: Comparative Lessons in Authority and Control. Princeton, NJ: Princeton University Press.

Hodler R and Raschky PA (2014) Regional favoritism. The Quarterly Journal of Economics 129(2), 995-1033.

Jablonski RS (2014) How aid targets votes: the impact of electoral incentives on foreign aid distribution. World Politics 66(2), 293-330.

Kalyvas SN (2006) The Logic of Violence in Civil War. Cambridge: Cambridge University Press.

King G (1986) How not to lie with statistics: avoiding common mistakes in quantitative political science. American Journal of Political Science 30(3), 666-687.

Kramon E and Posner DN (2013) Who benefits from distributive politics? How the outcome One studies affects the answer one gets. Perspectives on Politics 11(2), 461-474.

Kramon E and Posner DN (2016) Ethnic favoritism in education in Kenya. Quarterly Journal of Political Science 11(1), 1-58.

Kreutz J (2010) How and when armed conflicts end: introducing the UCDP conflict termination dataset. Journal of Peace Research 47(2), 243-250.

Levi M (1989) Of Rule and Revenue. Berkeley: University of California Press.

Lijphart A (1977) Democracy in Plural Societies. New Haven, CT: Yale University Press.

Louamy J (2008) Le Gnl Gueu Michel Sort de Sa Réserve : 'Il Faut Accepter Un Report Des Élections'. Available from https:/ bit.ly/2Lg8Dnb (accessed 13 May 2019).

Michalopoulos S and Papaioannou E (2013) Pre-colonial ethnic institutions and contemporary African development. Econometrica 81(1), 113-152.

Min B (2015) Power and the Vote: Elections and Electricity in the Developing World. Cambridge: Cambridge University Press.

Min B et al. (2013) Detection of rural electrification in Africa using DMSP-OLS night lights imagery. International Journal of Remote Sensing 34(22), 8118-8141.

Nickell S (1981) Biases in dynamic models with fixed effects. Econometrica 49(6), 1417-1426.

North DC, Wallis JJ and Weingast BR (2009) Violence and Social Orders: A Conceptual Framework for Interpreting Recorded Human History. Cambridge: Cambridge University Press.

Ottmann M (2012) Biting the Hand That Feeds You: Rebel Organisation and One-Sided Violence in Sub-Saharan Africa. Doctoral Dissertation, University of Nottingham.

Ottmann M and Vüllers J (2015) The power-sharing event dataset (PSED): a New dataset on the promises and practices of power-sharing in post-conflict countries. Conflict Management and Peace Science 32(3), 327-350.

Parks T, Colletta N and Oppenheim B (2013) The Contested Corners of Asia: Subnational Conflict and International Development Assistance. Bangkok, Thailand: The Asia Foundation.

Rainer I and Trebbi F (2016) New tools for the analysis of political power in Africa. In Edwards S, Johnson S and Weil DN (eds), African Successes, Volume I: Government and Institutions. Cambridge, MA: National Bureau of Economic Research, Inc, pp. 145-212.

Rosenbaum PR (2002) Observational Studies. Springer Series in Statistics. New York: Springer.

Ruggeri A, Dorussen H and Gizelis T-I (2018) On the frontline every day? Subnational deployment of United Nations Peacekeepers. British Journal of Political Science 48(4), 1005-1025.

Samii C (2016) Causal empiricism in quantitative research. The Journal of Politics 78(3), 941-955.

Sundberg R and Melander E (2013) Introducing the UCDP georeferenced event dataset. Journal of Peace Research 50(4), 523-532.

Tajima Y, Samphantharak K and Ostwald K (2018) Ethnic segregation and public goods: evidence from Indonesia. American Political Science Review 112(3), 637-653. 
Tollefsen AF, Strand H and Buhaug H (2012) PRIO-GRID: a unified spatial data structure. Journal of Peace Research 49(2), 363-374.

Utas M (ed.) (2012) African Conflicts and Informal Power: Big Men and Networks. London: Zed Books.

Vogt $\mathbf{M}$ et al. (2015) Integrating data on ethnicity, geography, and conflict: the ethnic power relations data set family. Journal of Conflict Resolution 59(7), 1327-1342.

Walter BF (2002) Committing to Peace: The Successful Settlement of Civil Wars. Princeton, NJ: Princeton University Press. Weidmann NB and Schutte S (2017) Using night light emissions for the prediction of local wealth. Journal of Peace Research 54(2), 125-140.

Wucherpfennig J et al. (2012) Ethnicity, the state, and the duration of civil war. World Politics 64(1), 79-115.

Wucherpfennig J et al. (2011) Politically relevant ethnic groups across space and time: introducing the GeoEPR dataset. Conflict Management and Peace Science 28(5), 423-437.

Cite this article: Haass F, Ottmann M (2021). Rebels, Revenue and Redistribution: The Political Geography of Post-Conflict Power-Sharing in Africa. British Journal of Political Science 51, 981-1001. https://doi.org/10.1017/S0007123419000474 